\title{
A multi-purpose system for corneal astigmatic marking
}

\section{Korneal astigmatik işaretleme için çok amaçlı bir sistem}

\author{
Ertuğrul Can ${ }^{1}$, Serkan Akkaya² \\ ${ }^{1}$ Ondokuz Mayıs University, Department of Ophthalmology, Faculty of Medicine, Samsun, Turkey \\ ${ }^{2}$ Kayseri Training and Research Hospital, Department of Ophthalmology, Kayseri, Turkey
}

Received: 02.09.2018

Accepted: 30.10 .2018

Doi: 10.21601/ortadogutipdergisi.456720

\begin{abstract}
Aim: To evaluate a new astigmatism marking system which creates corneal marks for proper toric intraocular lens (IOL) placement to improve results of premium IOL surgery and limbal relaxing incision surgery.

Material and Method: Patients were randomly allocated into two groups for preoperative corneal marking in the sitting position. A conventional pendulum marker and the new marking system were compared for vertical misalignment and rotational misalignment. A high-resolution anterior segment camera was used to document the corneal markings, and rotational deviation and vertical misalignment were evaluated.

Results: Each group consisted of 40 eyes and all marking points were clearly identified. The mean vertical misalignment in the pendulum marking group and in the new marking system group was $0,71 \pm 0,62 \mathrm{~mm}$ and 0,24 $\pm 0,12 \mathrm{~mm}$, respectively. There was a statistically significant difference in vertical misalignment between the two groups $(\mathrm{p}<0,05)$. The mean rotational deviation in the pendulum marking group and the new marking system group was 1,9 $\pm 2,4$ degrees and $0,8 \pm 1,3$ degrees respectively, showing a statistically significant difference $(\mathrm{p}<0,05)$.

Conclusion: While the conventional pendulum marker showed a certain amount of deviation and vertical misalignment, the new marking system marked the desired axis and minimized some possible measurement errors. During use of the new system, the entire cornea and conjunctiva were visible and the procedure was controlled perfectly.
\end{abstract}

Keywords: Astigmatism, cataract, cornea, marking, toric lens 


\section{Öz}

Amaç: Premium göz içi lens (GIL) cerrahisi ve limbal gevşetici insizyon cerrahisi sonuçlarını daha iyi hale getirmek amacıyla uygun torik GÍL yerleştirilmesi için kornea işaretleri oluşturan yeni bir astigmatizma işaretleme sistemini değerlendirmektir.

Gereç ve Yöntem: Hastalar oturma pozisyonunda preoperatif korneal işaretleme için rastgele iki gruba ayrıldı. Konvansiyonel bir sarkaç işaretleyici ve yeni işaretleme sistemi, dikey hizalama hatası ve rotasyonel hizalama hatası açısından karşılaştırıldı. Korneal işaretlerin belgelendirilmesinde yüksek çözünürlüklü ön segment kamera kullanıldı ve rotasyonel sapma ve dikey hizalama hatası değerlendirildi.

Bulgular: Her bir grup 40 gözden oluşmaktaydı ve tüm işaret noktaları açıkça tanımlandı. Sarkaç işaretleme grubunda ve yeni işaretleme sistemi grubunda ortalama dikey hizalama hatası sırasıly $0,71 \pm 0,62 \mathrm{~mm}$ ve $0,24 \pm$ $0,12 \mathrm{~mm}$ idi. İki grup arasında dikey sapmada istatistiksel olarak anlamlı bir fark vardı $(\mathrm{p}<0,05)$. Sarkaç işaretleme grubundaki ve yeni işaretleme sistemi grubundaki ortalama rotasyonel sapma sırasılla 1,9 $\pm 2,4$ derece ve $0,8 \pm 1,3$ derece idi ve iki grup arasında istatistiksel olarak anlamlı bir fark gösterdi $(\mathrm{p}<0,05)$.

Sonuçlar: Konvansiyonel sarkaç belirteci belirli bir miktar sapma ve dikey hizalama hatası gösterse de, yeni işaretleme sistemi istenen ekseni işaretlemiş ve bazı olası ölçüm hatalarını en aza indirmiştir. Yeni sistemin kullanımı sırasında tüm kornea ve konjonktiva görünür idi ve prosedür mükemmel şekilde kontrol edildi.

Anahtar Kelimeler: Astigmatizma, katarakt, kornea, işaretleme, torik lens

\section{Introduction}

Correcting corneal astigmatism during cataract surgery requires precise alignment of the steep meridian of astigmatism [1]. Most of the studies involving astigmatic marking on the cornea use a three-step procedure [2-4].

First, the horizontal axis of the eye before surgery is marked with the patient sitting in an upright position to correct for cyclotorsion. Second, a ring gauge is aligned to the limbus of the cornea with the patient lying on an operation table. Third, the desired axis is marked with a target axis marker. Precise marking of the steep meridian of astigmatism is required because misalignment may result in significant loss of astigmatism reduction. Many of the current traditional marking devices and methods sometimes fail to place the marks in the correct position $[5,6]$. A deviation of 10 degrees in marking results in a loss of approximately one-third of the desired astigmatism reduction [7].

We describe an astigmatic marking system which creates corneal marks for proper toric intraocular lens (IOL) placement to improve results of premium IOL surgery and limbal relaxing incision (LRI) surgery.

\section{Material and Method}

This randomized single-center study included patients who were candidates for cataract surgery. The study was approved by the local ethics committee and the experiments followed the tenets of the Declaration of Helsinki. Written informed consent was obtained from all participants. The patients had a complete ophthalmic examination before the study. They were randomly allocated into two groups, 40 in the pendulum-marking group and 40 in the new marking system group. Online randomization was performed to allocate each patient into one of two equally divided groups based on the marking device. All marking procedures were performed by the same examiner. The examiner had sufficient experience in both marking procedures. In the pendulum-marking group, the marking procedures were performed while the patients were sitting with their heads in an upright position. Because the pendular marker is only capable of marking the horizontal meridian, the marking procedures were performed along the horizontal meridian in both groups.

In the pendulum-marking group, a pendulum marker (Janach, Como, Italy) was dyed with an ink marker. After a drop of topical anesthetic was instilled in their eyes, the patients were asked to fixate on a distant target at their head level while the examiner marked the eye. The horizontal meridian was marked at the limbus (Figure 1). 


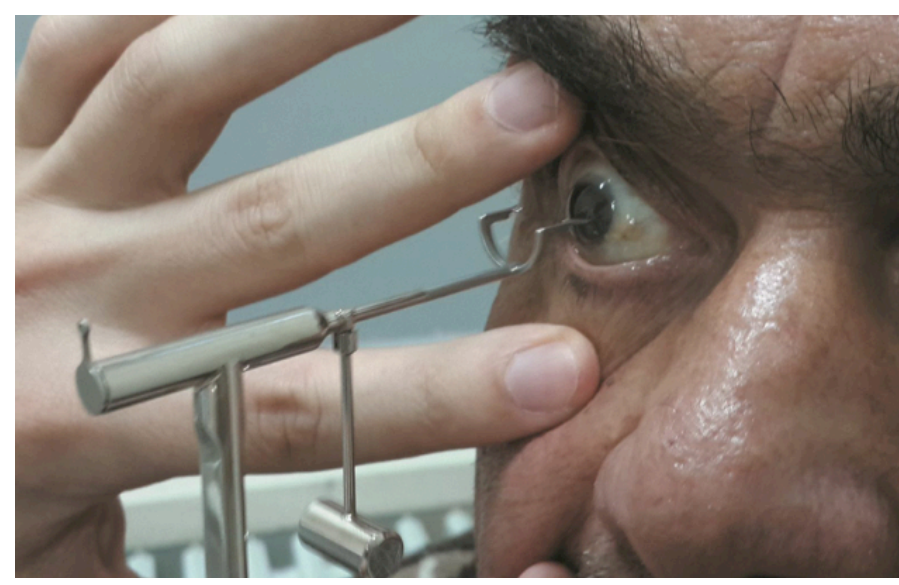

Figure 1. The pendulum marking technique.

To attain the proper head position, the temporal lid canthus of the eyes was adjusted to lines on the holding bars of the slit-lamp as described previously by Popp et al. [5]. In the new marking system group, a drop of topical anesthetic was first instilled in the eye as in the other group. The system used comprised a vertical stem with a ring gauge at the tip, and three different corneal marking devices including a corneal marking device with only toric marking blades, a corneal marking device with marking blades and a capsulorhexis centration marker, and a corneal marking device with blades for LRI (Figure 2A-D).

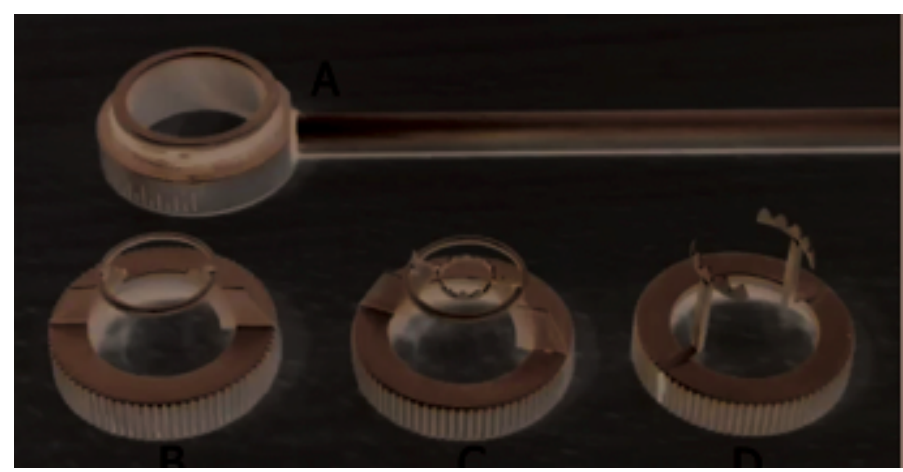

Figure 2A. A stem with a ring gauge at the tip. B. A corneal marking device with only toric marking blades. C. A corneal marking device with marking blades and a capsulorhexis centration marker.

D. A corneal marking device with blades for LRI.

The choice of device in the new system was at the surgeon's discretion. The ring gauge includes markings on the outer surface corresponding to $0-180$ degrees in fivedegree increments. The preferred corneal marking device is fitted securely adjacent to the corresponding part of the ring gauge and the surgeon can manually rotate the marker to align the radial blades with the markings on the outer surface of the ring gauge (Figure 3).

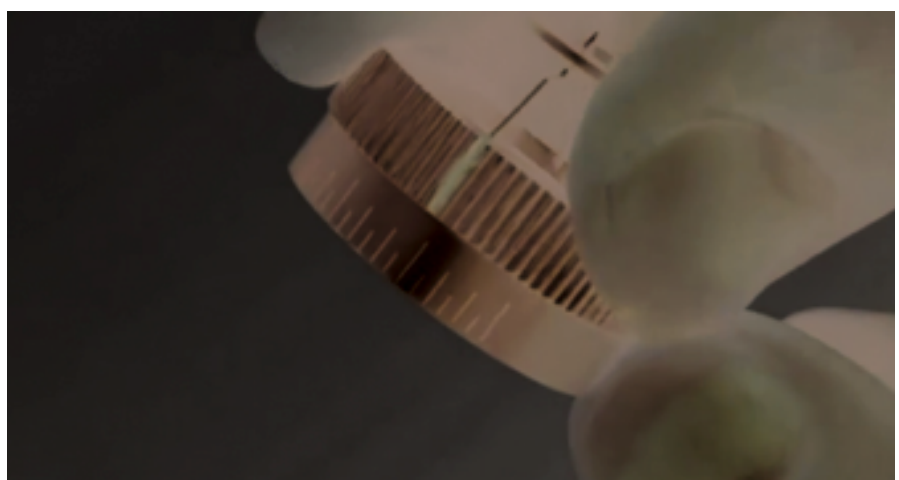

Figure 3. The surgeon can manually rotate the marker to align the radial blades with the markings on the outer surface of the ring gauge.

The instrument was inserted into the socket on the support point of the illumination rotation arm of the slit-lamp (Figure 4).

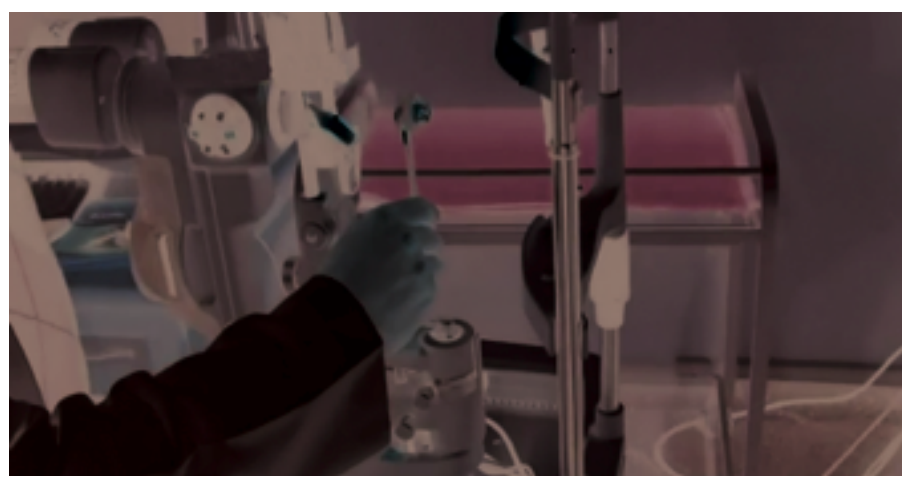

Figure 4. The instrument was inserted into the socket on the support point of the illumination rotation arm of the slit-lamp.

While the patient's position including the forehead was maintained using a chin rest and the eyelid was retracted, the examiner proceeded to mark the patient's eye. The ring with a $0,5 \mathrm{~mm}$ width at the distal side of the marking blades was used for alignment. The inner surface of the ring gauge was aligned with the limbus. Marking was performed by pressing the sharp edge of the blades or by application of ink to the sharp edge of the blades leaving a visible mark on the cornea (Figure 5).

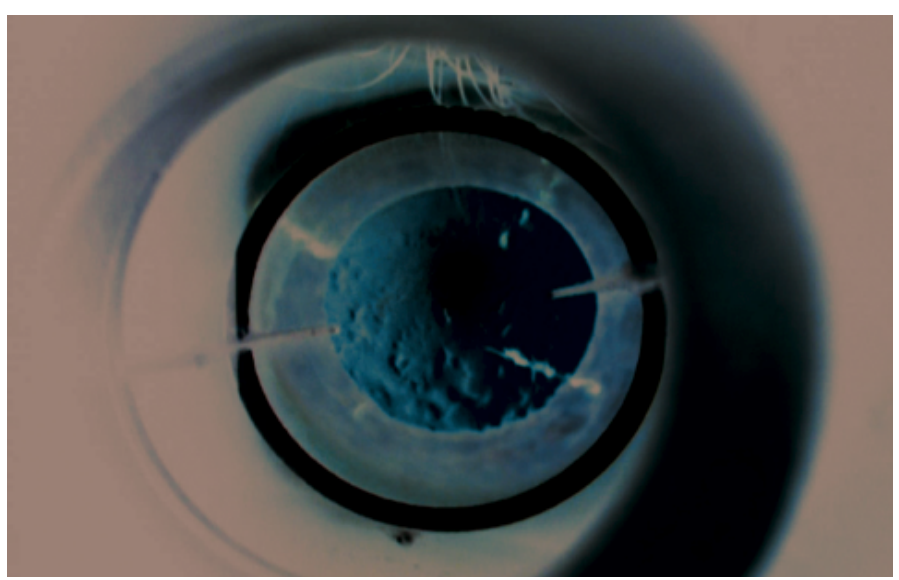


Figure 5. Marking was performed by pressing the sharp edge of the blades on the cornea.

After the marking procedures were done, a high-resolution anterior segment camera (Topcon DC-1 Digital Camera) was used to document the corneal markings. A different examiner evaluated the images of each cornea using an image analysis and processing software (Image J). For vertical misalignment analysis, a straight line passing through the center of corneal marks was drawn because the marks had some thickness preventing the examiner from making a fine comparison of the marked meridians. The distance between the straight line and the horizontal meridian passing through the center of the circle best fitting the limbus was calculated (Figure 6).

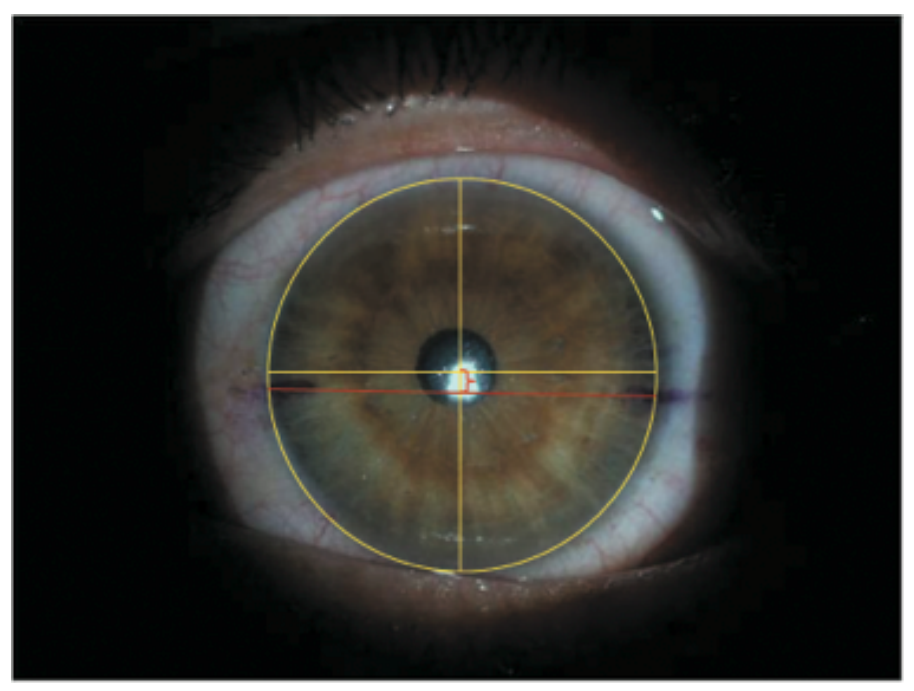

Figure 6. For vertical misalignment analysis, the distance between the straight line and the horizontal meridian passing through the center of the circle best fitting the limbus was calculated.

For rotational deviation analysis, the axis orientation of the straight line passing through the center of corneal marks was calculated and deviation of this value from the horizontal meridian was analyzed (Figure 7).

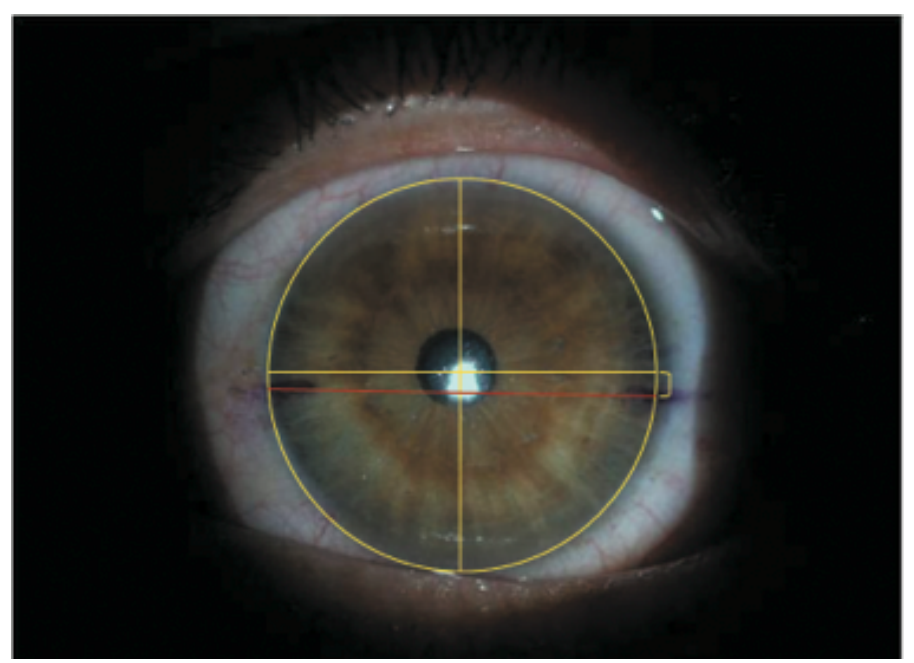

Figure 7. For rotational deviation analysis, the axis orientation of the straight linepassing through the center of corneal marks was calculated and deviation of this value from the horizontal meridian was analyzed.

Statistical analysis was performed using statistical software (SPSS version 21.0; SPSS, Inc., Chicago, IL, USA). Descriptive statistics for continuous variables were represented as mean $\pm \mathrm{SD}$. The Student's t-test was used to compare the data between the groups. Statistical significance was set at a p-value of $<0,05$.

\section{Results}

Eighty eyes of 80 patients who were candidates for cataract surgery were enrolled. The mean age was 38 years (range, 26-63 years). All marking points were clearly identified. The mean vertical misalignment in the pendulum marking group and in the new marking system group was $0,71 \pm$ $0,62 \mathrm{~mm}$ and $0,24 \pm 0,12 \mathrm{~mm}$ respectively, showing a statistically significant difference $(\mathrm{p}<0,05)$. The mean rotational deviation in the pendulum marking group and in the new marking system group was 1,9 $\pm 2,4$ degrees and $0,8 \pm 1,3$ degrees respectively, also showing a statistically significant difference $(p<0,05)$. These results indicate that the new system we used for axis marking is more accurate than the conventional method.

\section{Discussion}

The increasing popularity of toric IOLs have inspired surgeons to align these IOLs at the desired axis with a high degree of accuracy. To achieve successful surgical astigmatism correction outcomes, accurate marking of the cornea is very important. Surgeons need to mark the cornea while the patients are sitting in an upright position, because a significant amount of cyclorotation occurs when they are in a supine position.

It has been reported in a previous study that the average positional cyclorotation was four degrees, and eight percent of the 240 eyes in the study were rotated by 10 degrees [8]. In case of incorrect marking of the eye by surgeons, one degree of misalignment equals a 3,3\% decrease in antiastigmatic effect of the IOL.

Several methods have been described for proper alignment of a toric IOL. Popp et al. compared the results of slitlamp marking with an insulin needle, a pendular marker, a bubble marker, and a tonometer marker mounted on a Goldmann tonometer. A slight deviation from the horizontal reference meridian was observed with all devices [5]. Assuming that all these devices showed perfect vertical alignment, the horizontal alignment is still unclear. In 
cases with vertical or horizontal misalignment, the surgeon extrapolates the axis when using a ring-marking device. Most of current devices require two different additional instruments (after marking the horizontal meridian, a ring gauge and a target axis marker are required) and this can lead to measurement errors in each of the three individual steps. Some devices mounted on the Goldmann tonometer allow clear visualization through a barrel. Although they provide a single-step marking procedure, they have some disadvantages. They are mounted on the slit-lamp indirectly (Goldmann tonometry) with visualization done through a narrow barrel.

With such a device, marking is performed by centering the pupil; however, in case of a dilated pupil, correct alignment can be challenging. The marking system described in the present study has several advantages over conventional techniques. (1) It is a one-step marking procedure that minimizes some possible measurement errors occurring in three-step marking procedures. (2) Measurement is simple and can be performed with basic skills. (3) The entire cornea and conjunctiva are visible and the marking procedure can be controlled perfectly. (4) The system has a circle ring serving as a guide to align the limbus, minimizing vertical and horizontal misalignments. (5) An optional marking device with marking blades and a capsulorhexis centration marker enables the surgeon to make additional marks for successful capsulorhexis as well as successful multifocal IOL centration. (6) The marking blades have sharp points that leave lasting marks. (7) Another optional marking device enables the surgeon to mark the cornea for LRI for astigmatism correction.

Optimal visual results are achieved with correct marking and well centered IOLs. The new astigmatism marking system described here appears to be more accurate than the conventionally used marking methods.

Compared to approaches involving advanced technology that capture iris or conjunctival vessel patterns in digital images and perform calculations for more accurate markings, our technique is simpler and less expensive.

\section{Acknowledgments/Disclosure}

Funding/Support: This research did not receive any specific grant from funding agencies in the public, commercial, or not-for-profit sectors.

Financial Disclosures: " Dr. Ertuğrul Can has financial rights on the aforementioned marker as the inventor of the device."

Declaration of interest: The authors report no conflicts of interest.

\section{References}

1. Ma JJ, Tseng SS. Simple method for accurate alignment in toric phakic and aphakic intraocular lens implantation. J Cataract Refract Surg 2008; 34: 1631-6.

2. Mendicute J, Irigoyen C, Aramberri J, Ondarra A, Montes-Mico R. Foldable toric intraocular lens for astigmatism correction in cataract patients. J Cataract Refract Surg 2008; 34: 601-7.

3. Koshy JJ, Nishi Y, Hirnschall N, et al. Rotational stability of a single-piece toric acrylic intraocular lens. J Cataract Refract Surg 2010; 36: 1665-70.

4. Alio JL, Pinero DP, Tomas J, Plaza AB. Vector analysis of astigmatic changes after cataract surgery with implantation of a new toric multifocal intraocular lens. J Cataract Refract Surg 2011; 37: $1217-29$.

5. Popp N, Hirnschall N, Maedel S, Findl O. Evaluation of 4 corneal astigmatic marking methods. J Cataract Refract Surg 2012; 38: 2094-9.

6. Visser N, Berendschot TT, Bauer NJ, Jurich J, Kersting O, Nuijts RM. Accuracy of toric intraocular lens implantation in cataract and refractive surgery. J Cataract Refract Surg 2011; 37: 1394-402.

7. Felipe A, Artigas JM, Diez-Ajenjo A, Garcia-Domene C, Alcocer $\mathrm{P}$. Residual astigmatism produced by toric intraocular lens rotation. J Cataract Refract Surg 2011; 37: 1895-901.

8. Swami AU, Steinert RF, Osborne WE, White AA. Rotational malposition during laser in situ keratomileusis. Am J Ophthalmol 2002; 133: 561-2.

Corresponding Author: Serkan Akkaya, Kayseri Training and Research Hospital, Department of Ophthalmology, 38080, Kayseri, Turkey

Email: drsakkaya@gmail.com 